\title{
DAMPAK KULIAH DARING TERHADAP KESEHATAN MENTAL MAHASISWA DITINJAU DARI ASPEK PSIKOLOGI
}

\author{
Fitria Amalia Rochimah \\ Program Studi Psikologi, Fakultas Kedokteran, Universitas Lambung Mangkurat, \\ Jl. A. Yani Km 36,00 Banjarbaru Kalimantan Selatan, 70714, Indonesia \\ E-mail:2010914220035@mhs.ulm.ac.id
}

\begin{abstract}
ABSTRAK
Penelitian ini bertujuan untuk mengetahui apa saja dampak yang ditimbulkan dari kuliah daring bagi mahasiswa dan bagaimana cara mahasiswa untuk mengatasi memburuknya kesehatan mental mahasiswa tersebut yang dikarenakan kuliah daring. Penelitian ini menggunakan metode kajian literatur. Sumber dari kajian literatur ini diambil dari beberapa jurnal dan buku yang berasal dari sumber terpercaya dan dari beberapa dosen Universitas Lambung Mangkurat. Berdasarkan hasil penelitian, diketahui bahwa dampak yang ditimbulkan karena kuliah daring terdiri dari dampak positif dan dampak negatif. Dampak negatif inilah yang dapat menyerang kesehatan mental seorang mahasiswa selama kuliah daring. Mahasiswa pun melalukan beberapa upaya yang menurutnya ampuh untuk mengatasi permasalahan mental dirinya tersebut.
\end{abstract}

Keywords: kesehatan mental, kuliah daring, mahasiswa

\section{ABSTRACT}

This study aims to determine the impact of online lectures on students and how students can overcome the deteriorating mental health of these students due to online lectures. This research uses literature review method. Sources of this literature review are taken from several journals and books that come from trusted sources and from several lecturers at Lambung Mangkurat University. Based on the results of the research, it is known that the impact caused by online lectures consists of positive impacts and negative impacts. This negative impact can affect a student's mental health during online lectures. Students also make several efforts which according to them are effective in overcoming these mental problems.

Keywords: mental health, online lectures, students

\section{PENDAHULUAN}

Kesehatan merupakan hal yang penting karena kesehatan berperan dalam keberfungsian semua aspek kehidupan bagi seluruh masyarakat. Undang-undang kesehatan No. 23 tahun 1992 menyatakan: kesehatan adalah keadaan sejahtera dari badan, jiwa, dan sosial yang memungkinkan setiap orang hidup produktif secara sosial dan ekonomis [1]. Pengertian kesehatan menurut WHO (World Health Organization) merupakan kondisi kesejahteraan fisik, mental, dan sosial dan bukan hanya ketiadaan penyakit atau kecacatan [2]. Berdasarkan definisi tadi, dapat disimpulkan bahwa mental merupakan salah satu penunjang kesehatan sehingga kesehatan mental tidak dapat diabaikan begitu saja.

Kesehatan mental merupakan hal yang mulai dibicarakan dan diperhatikan secara serius oleh masyarakat Indonesia pada saat ini. Masalah kesehatan mental di Indonesia pada masa ini masih tergolong sangat tinggi, terutama pada kalangan remaja karena mereka masih memiliki emosi yang tidak stabil dan 
belum memiliki kemampuan yang baik untuk memecahkan masalah yang ada. Masa remaja merupakan masa dimana mereka sering mengalami stres terutama pada peristiwaperistiwa tertentu dalam hidup mereka [3]. Remaja dianggap sebagai golongan yang rentan untuk mengalami gangguan mental. Oleh karena itu, remaja perlu untuk mendapatkan perhatian lebih karena remaja merupakan aset negara dan generasi penerus bangsa [4].

Kesehatan mental pada mahasiswa dapat dipengaruhi oleh beberapa faktor, diantaranya yaitu faktor genetika, keluarga, pertemanan, gaya hidup, sosial, dan berbagai faktor lainnya. Faktor-faktor tersebut dapat mempengaruhi mahasiswa secara positif maupun negatif. Akan tetapi, masih banyak mahasiswa yang tidak menyadari dampak positif dan negatif yang ditimbulkan dari faktor-faktor tersebut sehingga mereka lupa akan kesehatan mental mereka. Mereka lupa untuk berfokus pada kesehatan mental mereka karena mereka hanya berfokus pada tugas, organisasi, jadwal kuliah, serta tuntutantuntutan yang ia terima dari orang-orang di sekitarnya.

Regulasi diri dalam belajar yang baik akan membantu mahasiswa untuk memenuhi tuntutan-tuntutan yang dihadapinya [5]. Regulasi diri adalah kemampuan seseorang untuk melakukan kontrol terhadap emosi dan perilakunya di situasi apapun secara mandiri. Mahasiswa dianjurkan untuk bisa melakukan regulasi diri karena regulasi diri berkaitan terhadap kesehatan mental mahasiswa. Tanpa adanya regulasi diri, mahasiswa akan kesulitan untuk mengontrol dan mengatur emosi, perilaku, dan tingkahlakunya. Ketidakmampuan mahasiswa untuk melakukan regulasi diri akan mengakibatkan mentalnya terganggu karena tidak bisa mengontrol diri di situasi tertentu.

Pada awal masa COVID-19, pemerintah resmi menyatakan bahwa semua instansi pendidikan akan melaksanakan pembelajaran secara daring (media dalam jaringan) pada bulan Maret 2020. Awalnya, semua sekolah dan universitas diliburkan selama 2 minggu. Akan tetapi, dikarenakan kondisi yang tidak memungkinkan, maka pemerintah memutuskan untuk melaksanakan pembelajaran secara daring sebagai pencegahan agar angka pada kasus COVID-19 tidak meningkat.

Berawal dari kuliah daring, kita dapat melihat bagaimana dampak yang ditimbulkan terhadap para mahasiswa melalui kuliah daring tersebut, terutama pada mahasiswa baru. Seharusnya, masa perkuliahan awal merupakan kesempatan bagi mahasiwa baru untuk mencari relasi, mengembangkan diri, serta belajar untuk menjadi lebih mandiri. Akan tetapi, sekarang hal itu menjadi lebih sulit untuk dilakukan karena ketidakmampuan mahasiswa untuk berinteraksi secara langsung sehingga hal-hal yang seharusnya menjadi kesempatan emas bagi mahasiswa baru pun hilang.

Kesehatan mental memiliki peranan yang sangat penting bagi mahasiswa baru untuk beradaptasi dengan lingkungan perkuliahannya yang baru. Tentunya kehidupan di lingkungan kampus dan sekolah jauh berbeda. Mahasiswa baru akan menemukan berbagai macam pergaulan yang sangat beragam serta akan menemukan metode pembelajaran yang berbeda dibanding masa sekolah. Oleh karena itu, secara tidak langsung mahasiswa baru dituntut untuk bisa beradaptasi terhadap lingkungan barunya.

Selain mahasiswa baru, mahasiswa lama pun mengalami beberapa dampak yang diakibatkan oleh kuliah daring, terutama bagi mahasiswa yang mengikuti organisasi. Dengan adanya kuliah daring, maka secara otomatis tugas-tugas perkuliahan pun akan semakin banyak. Mahasiswa yang terlibat aktif dan terlalu berfokus pada organisasi kemahasiswaan dapat memiliki sikap untuk menunda pekerjaan atau prokrastinasi akademik, yaitu penundaan dalam hal mengerjakan tugas-tugas kuliah maupun penundaan untuk terlibat penuh di perkuliahan [6]. Jika penundaan ini terus berlanjut, hal ini dapat mengganggu aktivitas mereka dalam memenuhi kewajiban sebagai mahasiswa, seperti mengerjakan tugas tepat waktu. Dikarenakan tugas perkuliahan yang semakin banyak ketika daring, maka mahasiswa yang mengikuti organisasi akan semakin kewalahan dengan adanya tugas perkuliahan dan tugas dari organisasi jika mereka tidak dapat memanajemen waktu dengan baik. 
Penelitian ini dilakukan dengan tujuan untuk mengetahui apa saja dampak-dampak yang ditimbulkan dari kuliah daring yang dapat menyebabkan permasalahan mental mahasiswa serta apa saja upaya yang dilakukan mahasiswa dalam mengatasi permasalahan mentalnya yang diakibatkan oleh kuliah daring.

\section{METODE}

Dalam melakukan penulisan penelitian, penulis menggunakan teknik penyusunan secara sistematis agar langkah-langkah yang diambil dapat dilakukan dengan cara yang lebih mudah. Metode yang digunakan pada penelitian kali ini adalah metode kajian literatur. Referensi memuat hal tentang: (a) kesehatan mental, (b) dampak kuliah daring, dan (c) upaya menangani gangguan mental. Referensi didapat dari beraneka variasi sumber pustaka dari beberapa sumber terpercaya, serta beberapa jurnal dan buku dari beberapa dosen Universitas Lambung Mangkurat yang didapatkan melalui Google Scholar.

\section{HASIL DAN PEMBAHASAN}

\section{Konsep Kesehatan Mental}

Sehat secara mental adalah keadaan dimana seseorang dapat tumbuh serta berkembang secara positif. Individu tersebut dapat tumbuh dan berkembang secara baik, matang dalam hidupnya, bersedia menerima tanggung jawab, serta menemukan penyesuaian dalam berpartisipasi dalam memelihara aturan sosial dan tindakan terhadap budayanya. Kesehatan mental tentunya memiliki peran penting dalam kehidupan, terutama pada bidang kesehatan. Kesehatan tidak hanya tentang sehat fisik, tetapi juga sehat mental. Jika kedua hal ini tidak selaras, maka seseorang tidak dapat dimasukkan ke dalam kategori sehat.

Kesehatan jiwa menurut WHO (World Health Organization) yaitu ketika seseorang merasa sehat dan bahagia pada dirinya, mampu menghadapi tantangan dalam hidup, dapat menerima orang lain sebagaimana seharusnya, serta mempunyai sikap positif terhadap diri sendiri dan orang lain [7]. Kesehatan jiwa dapat diartikan sebagai terbentuknya hal-hal positif yang ada di dalam jiwa atau diri seseorang.

\section{Dampak Kuliah Daring Bagi Mahasiswa}

Pandemi Corona Virus Disease (COVID19) menyebabkan berbagai bidang merasakan dampaknya. Dampak tersebut tidak hanya dirasakan oleh bidang ekonomi, tetapi juga dirasakan oleh bidang pendidikan. Semenjak Pembatasan Sosial Berskala Besar (PSBB), masyarakat diwajibkan untuk bekerja dan melaksanakan segala aktivitas di rumah masing-masing atau biasanya dikenal dengan istilah "Work From Home" (WFH). Semua masyarakat tidak diperbolehkan untuk keluar rumah kecuali jika ada keadaan yang mendesak. Dikarenakan hal tersebut, maka semua sekolah dan kampus diliburkan serta pembelajaran dilaksanakan secara daring (online).

Kuliah daring atau biasanya disebut sebagai kuliah online merupakan pelaksanaan pembelajaran di perguruan tinggi yang dilaksanakan secara jarak jauh melalui platform atau media dan terhubung dengan jaringan. Perguruan tinggi merupakan wadah bagi mahasiswa untuk mengembangkan kemampuan dan mempersiapkan diri menjadi tenaga-tenaga profesional yang akan mengarahkan para mahasiswa menjadi sumber daya manusia yang berkompeten di bidangnya masing-masing [8]. Dilaksanakannya kuliah daring yaitu disebabkan oleh terjadinya COVID-19 di Indonesia. Kuliah daring dilaksanakan dengan maksud untuk mencegah serta mengurangi angka dari orang yang terkena COVID-19.

Pengguna jejaring sosial dapat bebas untuk menunjukkan berbagai perasaan, pengalaman, dan pengetahuan di antara anggota online [9]. Dalam perkuliahan daring, tentunya platform sangat dibutuhkan dalam perkuliahan. Platform yang biasanya digunakan oleh dosen dan mahasiswa untuk melakukan pembelajaran daring yaitu Zoom, Google Meet, Google Classroom, E-Learning, dan sebagainya. Tanpa adanya platform tersebut, maka pembelajaran kuliah daring akan sulit dan bahkan tidak dapat untuk dilaksanakan. 
Kuliah daring tentunya memiliki dampak positif dan dampak negatif terhadap mahasiswa. Dampak positif dengan adanya kuliah daring yaitu diantaranya:

a. Memiliki waktu lebih banyak untuk mengerjakan tugas

Selama perkuliahan daring, tentunya mahasiswa diberi lebih banyak tugas oleh dosen dibandingkan perkuliahan luring. Tugas-tugas yang diberikan pun sebagian besar merupakan tugas individu karena agak sulit bagi mahasiswa untuk mengerjakan tugas kelompok ketika di masa pandemi seperti ini. Dengan adanya kuliah daring, maka mahasiswa memiliki waktu lebih banyak untuk mengerjakan tugas karena saat kuliah daring seperti ini mahasiswa biasanya hanya diberikan tugas individu dan walaupun ada tugas kelompok pun, mahasiswa hanya perlu mengerjakan tugas tersebut di rumah masing-masing tanpa harus berkumpul dengan teman-teman kelompoknya.

b. Tidak perlu pergi ke kampus

Dikarenakan pihak universitas tidak memperbolehkan untuk melakukan pembelajaran di kampus, maka mahasiswa tidak perlu pergi ke kampus dan hanya perlu mengikuti perkuliahan melalui platform yang telah disediakan. Hal ini memiliki dampak positif karena mahasiswa hanya perlu mengeluarkan sedikit tenaga ketika hendak melaksanakan pembelajaran. Mahasiswa hanya perlu membuka laptop atau handphone serta membuka platform yang akan digunakan, lalu mahasiswa pun bisa mengikuti pembelajaran tanpa mengeluarkan banyak tenaga.

c. Perkuliahan dapat dilakukan dimana dan kapan saja

Selama kuliah daring, semua aktivitas perkuliahan dilakukan melalui jejaring sosial. Mahasiswa hanya perlu melakukan perkuliahan melalui platform dan tidak perlu pergi ke kampus. Hal ini memberi kesempatan bagi mahasiswa untuk tetap dapat mengikuti perkuliahan walaupun mahasiswa tersebut sedang sibuk atau sedang berada di luar rumah.

Dampak negatif dengan adanya kuliah daring yaitu diantaranya:

a. Sulit untuk memahami materi

Bagi mahasiswa, pemberian materi ketika perkuliahan luring tentunya lebih mudah diterapkan serta dicerna oleh mahasiswa. Sulit untuk mahasiswa memahami materi ketika perkuliahan daring karena mahasiswa tidak dapat diawasi secara langsung ketika perkuliahan sehingga menyebabkan mahasiswa dapat lebih mudah mengalihkan perhatiannya ke objek lain, contohnya handphone.

b. Sulit untuk berkomunikasi dengan teman

Kita semua pastinya sepakat bahwa komunikasi akan menjadi lebih mudah jika dilakukan dengan bertemu langsung dan dilakukan secara tatap muka. Dengan jarak yang jauh antara mahasiswa dengan mahasiswa lainnya, maka mereka akan sulit untuk saling melakukan komunikasi. Kesulitan dalam hal komunikasi akan lebih terasa ketika mahasiswa bekerja dalam kelompok. Mahasiswa akan lebih sulit untuk bertukar pendapat dan mengerjakan tugas kelompok karena terkadang ada beberapa mahasiswa yang terkendala jaringan, sehingga itu menyebabkan mereka kesulitan ketika hendak berdiskusi.

c. Tugas menjadi lebih banyak

Mahasiswa dituntut untuk bersikap kritis, bertanggung jawab, dewasa, mandiri, memiliki prestasi yang baik, serta dapat menyelesaikan tugas-tugasnya dengan baik, dimana tujuan diberikannya tugas-tugas tersebut yaitu untuk mengetahui sejauh mana kompetensi atau kemampuan mahasiswa tersebut dalam bidang akademik [10]. Akan tetapi, tugas yang diberikan oleh dosen selama perkuliahan daring menjadi lebih banyak dan deadlinenya pun cenderung singkat. Hal ini 
menyebabkan mahasiswa kesulitan untuk membagi waktu dan bingung hendak mengerjakan tugas yang mana terlebih dahulu.

\section{Permasalahan Mental yang Dialami Mahasiswa Selama Kuliah Daring}

Kesehatan mental dipengaruhi oleh pengalaman serta lingkungan seseorang dan berdampak pada perilaku serta kepribadian. Pengalaman dan lingkungan yang baik dapat mengantarkan seseorang memiki perilaku dan kepribadian yang baik. Sebaliknya, pengalaman dan lingkungan yang buruk dapat mengantarkan seseorang untuk memiliki perilaku dan kepribadian yang buruk. Oleh karena itu, penting bagi kita sebagai manusia untuk memilih lingkungan yang baik dan menjalani hidup secara baik pula.

Manusia merupakan makhluk sosial yang memerlukan interaksi dengan manusiamanusia lainnya, sehingga pastinya manusia membutuhkan interaksi walaupun derajat kebutuhan interaksi setiap manusia berbedabeda. Sebagai makhluk sosial, manusia akan selalu hidup bersama dan tidak bisa untuk melakukan sesuatu tanpa memikirkan hal-hal yang ada di sekitarnya [11]. Ada yang merasa cukup dengan hanya berinteraksi dengan beberapa orang saja, tetapi ada juga yang ingin mempunyai interaksi lebih banyak dengan orang-orang di sekitar. Dengan adanya pandemi seperti ini, mahasiswa tidak bisa untuk bertemu dengan teman-temannya Walau hanya untuk sekadar bercanda gurau. Selain itu, mahasiswa juga kehilangan momenmomen kecil, sehingga mereka merasakan kesepian dan hal itu dapat menyebabkan mahasiswa menjadi stres. Akan tetapi, mahasiswa tidak dapat meredakan stres tersebut dengan sekadar berjalan-jalan atau berkumpul dengan teman-teman dikarenakan ada pandemi seperti ini.

Kuliah daring tentunya memberikan dampak positif dan negatif terhadap mahasiswa. Akan tetapi, tidak sedikit mahasiswa yang merasakan bahwa kuliah daring memberi lebih banyak dampak negatif daripada dampak positif. Banyak mahasiswa yang mengeluh dan merasakan bahwa kesehatan mental yang ada pada dirinya semakin memburuk selama pelaksaan kuliah daring. Salah satu pemicu dampak negatif tersebut yaitu keluarga, terutama orangtua. Setidaknya, sikap penerimaan dari orangtua dapat mengatasi atau mengurangi efek negatif dari kesulitan-kesulitan saat menghadapi tugas akademis dan dapat meningkatkan keterlibatan mahasiswa dalam aktivitas di kampus, sehingga hal tersebut dapat membawa mahasiswa untuk selalu termotivasi dan sukses dalam melewati tugas-tugas sulitnya sebagai mahasiswa saat perkuliahan daring [12]. Akan tetapi, terkadang ada orangtua yang tidak dapat mengerti kesulitan anaknya ketika masa kuliah daring seperti ini, sehingga hal tersebut menyebabkan anak dapat merasa depresi dan stres.

Hal-hal yang memicu dampak negatif dari kuliah daring tersebut dapat membuat mahasiswa menjadi stres. Hal ini dapat menyebabkan mahasiswa tidak mampu untuk fokus dan tidak mampu untuk mengerjakan tugas-tugasnya dengan baik. Jika hal ini berlangsung dalam waktu yang lama, maka mahasiswa akan memiliki kemungkinan untuk mengalami gangguan kesehatan mental yang lebih serius dan perlu ditangani oleh profesional.

\section{Upaya Mahasiswa untuk Menanggulangi Permasalahan Mental Dirinya}

Mahasiswa sebagai pelajar diharapkan untuk dapat menerima dan menyelesaikan tuntutan-tuntutan yang ada sehingga mahasiswa membutuhkan yang namanya self efficacy dan coping stres. Self efficacy adalah keyakinan individu terhadap kemampuan yang ia miliki, sedangkan coping stres merupakan upaya seseorang yang dilakukan dengan tujuan untuk mengatasi tuntutan-tuntutan yang dihadapinya [13]. Self efficacy berguna bagi mahasiswa untuk meyakini bahwa dirinya pasti bisa untuk melakukan suatu perilaku dalam situasti tertentu. Melalui keyakinan diri tersebut, mahasiswa akan memiliki coping stres yang tinggi sehingga mahasiswa dapat mengatasi permasalahannya dengan baik.

Mahasiswa tentunya tidak ingin jika ia memiliki gangguan pada mentalnya. Mereka pasti ingin untuk selalu sehat baik secara fisik maupun mental. Bila pikiran mahasiswa 
difasilitasi untuk memikirkan bahwa dirinya sakit, maka sakit tersebut bisa menjadi nyata [14]. Oleh karena itu, mahasiswa dianjurkan untuk selalu berpikiran positif terhadap berbagai hal. Akan tetapi, terkadang mahasiswa tidak dapat mengetahui apakah hal yang telah ia jalani pada hari ini dapat berdampak pada mentalnya untuk di kemudian hari atau tidak. Ada mahasiswa yang tahan jika dirinya berada dalam tekanan, tetapi ada juga mahasiswa yang tidak tahan jika dirinya berada di dalam tekanan, sehingga hal tersebut menimbulkan dampak pada mentalnya.

Mahasiswa memiliki upayanya tersendiri dalam menanggulangi masalah mentalnya. Beberapa upaya yang mahasiswa lakukan untuk menanggulangi masalah mentalnya yaitu dengan bersikap santai terhadap semua hal yang dijalaninya, menghibur diri sendiri, bercerita kepada orang terdekat, dan lain sebagainya. Akan tetapi, bagi mahasiswa yang memiliki gangguan serius pada mentalnya, ia akan lebih memilih untuk ke psikolog atau psikiater. Cara-cara tersebut merupakan cara positif yang dapat dilakukan seorang mahasiswa untuk mengatasi permasalahan mental dirinya. Akan tetapi, ada juga mahasiswa yang selalu memendam permasalahannya sendiri. Sebenarnya cara ini tidak dibenarkan, tetapi balik lagi bahwa setiap mahasiswa pasti memiliki upaya untuk mengatasi permasalahan mentalnya sendiri dengan cara yang berbeda-beda.

Hal yang paling penting yang harus dilakukan mahasiswa untuk menghadapi permasalahan mental ketika kuliah daring yaitu dengan mengendalikan diri, menjinakkan emosi, berusaha secara maksimal untuk mengelola perasaan negatif, serta mengalihkan segala aspek negatif dengan menjalani hobi yang dapat dilakukan dan mencoba untuk mengubah pola pikir [15]. Akan menjadi percuma jika melakukan berbagai upaya untuk mengatasi permasalahan mental tetapi tidak diiringi dengan pengendalian emosi.

\section{KESIMPULAN}

Berdasarkan dari hasil kajian di atas, dapat diketahui bahwa mahasiswa merasakan dampak positif dan negatif selama dilaksanakannya kuliah daring. Akan tetapi, tidak sedikit mahasiswa yang hanya merasakan dampak negatif saja dari perkuliahan daring. Dampak negatif yang ditimbulkan dari kuliah daring tersebutlah yang dapat menyerang mental mahasiswa. Jika seorang mahasiswa hanya memikirkan dampak negatif dari perkuliahan daring, maka mahasiswa akan menjadi stres dan dapat menyebabkan mahasiswa untuk memiliki permasalahan mental. Oleh karena itu, mahasiswa berusaha untuk tetap sehat secara mental dengan melakukan beberapa upaya yang menurutnya ampuh untuk mengurangi rasa stres dan mengatasi permasalahan mentalnya.

Dikarenakan adanya dampak negatif tadi, kiranya pihak kampus atau pihak pendidikan dapat memberikan kenyamanan bagi setiap mahasiswa ketika perkuliahan daring berlangsung. Contohnya yaitu dengan tidak memberikan tugas terlalu banyak, dapat memberikan materi dengan cara yang lebih menarik, serta memaklumi jika mahasiswa tidak sengaja keluar dari Zoom atau Google Meet karena permasalahan jaringan. Dengan hal-hal tersebut, mahasiswa dapat meredakan sedikit rasa stresnya karena bebannya telah sedikit berkurang.

\section{DAFTAR PUSTAKA}

1. Indonesia, P. R., \& Indonesia, P. R. (1992). Undang Undang No. 23 Tahun 1992 Tentang: Kesehatan. Undang Undang, 23, 1-31.

2. World Health Organization. (2003). Kesehatan Mental dalam Kedaruratan. Retrieved from Aspek Mental dan Sosial Kesehatan Masyarakat yang Terpapar Stresor yang Ekstrem website: https://www. who. int/mental_health/resources/mental_healt h_in_emergen ices_bahasa.pdf.

3. Yayan, M., Yuniarrahmah, E., \& Anward, H. H. (2017). Gambaran regulasi diri dan perilaku kenakalan seksual pada remaja di Batulicin. Jurnal Ecopsy, 3(2).

4. Yuniarrahmah, E., \& Rachmah, D. N. (2016). Pola asuh dan penalaran moral pada remaja yang sekolah di madrasah dan sekolah umum di Banjarmasin. Jurnal Ecopsy, 1(2). 
5. Rachmah, D. N. Regulasi Diri dalam Belajar pada Mahasiswa yang Memiliki Peran Banyak.

6. Rachmah, D. N., Mayangsari, M. D., \& Akbar, S. N. (2015). Motivasi belajar sebagai mediator hubungan kecerdasan adversitas dan prokrastinasi akademik pada mahasiswa yang aktif berorganisasi. Jurnal Cakrawala Pendidikan, 34(2).

7. Riani, B. R. (2017). Hubungan Persepsi Diri, Sosial dan Keluarga Dengan Kesepian Pada Klien Skizofrenia Di Unit Pelayanan Jiwa A (UPJA) RSJ. Prof. HB. Saanin Padang (Doctoral dissertation, Universitas Andalas).

8. Putri, C. P., Mayangsari, M. D., \& Rusli, R. (2020). PENGARUH STRES AKADEMIK TERHADAP ACADEMIC HELP SEEKING PADA MAHASISWA PSIKOLOGI UNLAM DENGAN INDEKS PRESTASI KUMULATIF RENDAH. Kognisia prodi Psikologi FK ULM, 1(2), 28-37.

9. Aridarmaputri, G. S., Akbar, S. N., \& Yuniarrahmah, E. (2016). Pengaruh jejaring sosial terhadap kebutuhan afiliasi remaja di program Studi Psikologi Fakultas Kedokteran Universitas Lambung Mangkurat. Jurnal Ecopsy, 3(1).

10. Putri, C. P., Mayangsari, M. D., \& Rusli, R. (2020). PENGARUH STRES AKADEMIK TERHADAP ACADEMIC HELP SEEKING PADA MAHASISWA PSIKOLOGI UNLAM DENGAN INDEKS PRESTASI KUMULATIF RENDAH. Kognisia prodi Psikologi FK ULM, 1(2), 28-37.

11. Putri, L. A., Anward, H. H., \& Zwagery, R. V. (2020). PERBEDAAN KUALITAS PERSAHABATAN DITINJAU DARI GAYA KELEKATAN PADA MAHASISWA PSIKOLOGI FAKULTAS KEDOKTERAN ULM. Kognisia prodi Psikologi FK ULM, 1(1), 23-28.

12. Mayangsari, M. D. (2016). Motivasi Berprestasi Mahasiswa Ditinjau dari Penerimaan Orangtua. Jurnal Ecopsy, 1(1).

13. Rachmah, D. N. (2013). Hubungan self eficiecy, coping stress, dan prestasi akademik. Jurnal ecopsy, 1(1), 1-2.

14. WARMANSYAH ABBAS, E. R. S. I. S. (2020). Menulis di Era Covid-19:
Memanage Trauma Psikologis Menghindari Psikosomatis. Menulis di Era Covid-19: Memanage Trauma Psikologis Menghindari Psikosomatis.

15. Abbas, E. W., \& Erlyani, N. (2020). Menulis di Kala Badai Covid-19. 